\title{
Factors Affecting Employees' Trust in Management
}

\author{
Binod Ghimire, Ph.D. \\ Lecturer \\ Nepal Commerce Campus, Faculty of Management, T.U.
}

\begin{abstract}
Employees' commitment is an important issue in an organization which is the outcome of sense of trust. All relationships and interactions are formed and based in the sense of trust. It is equally important in workplace relationship. Trust tends to have a strong impact on the relationships between hospital managers and nursing employees. It increases commitment level of nurses. This study focuses on three components of trust in management: competency, integrity and benevolence. The aim of this study is to understand factors affecting employees' trust in the management among nursing employees of hospitals in Nepal. Nurses are the crucial human resources in health care organization and their commitment play vital role for the overall objective of the hospitals. This study is an analytical and descriptive study based on nursing employees. Using multi-stage purposive sampling, four hundred sixty five nurses were chosen as a sample of the study. This research paper advances a theoretical model stating the factors affecting the employees' trust in management resulted into three variables.
\end{abstract}

Keywords: Nurses, Trust in management, Employees' Commitment

\section{Introduction}

Trust tends to have a strong impact on the relationships between managers and employees. In a work context, without some foundation of trust, social relations cannot develop. Trust on administrators is defined as willingness of employees with the attitudes and actions (Mayer and others, 1995). Organizational trust is the employees' willingness to be informed organization as well as trust in the fairness of the other individuals and groups depending on the organization's cultural structure and ability of communication (Mishra, 1996).

Trust is an essential component for all nature of management. Employees determine whether they trust to the organization depending on results they attain from the interactions with managers. Trust is intangible in nature but it helps to understand interpersonal and group behavior and managerial effectiveness. Trust is essential for cooperation and it leads to constructive behavior which is vital for relationships. Trust is linked to individual human behavior and effective group organization functioning in a number of studies (NyhanMarlowe, 1997). Trust refers to employee faith in organizational leaders and the belief that ultimately organizational actions will prove beneficial for employees. (Heather- Laschinger- Finegan and Shamian, 2001). Supervisors play key roles in increasing employees' attitudes toward organization and themselves. When supervisors communicate clearly and make fair decisions, employees trust them more (Whitener, 1997). High levels of trust are positively and causally linked with organizational commitment. Researchers found that /organizational trust is a significant predictor of organizational commitment (Gilbert and Tang, 1998). There are other studies also that have found positive association between trust and affective commitment. All these give evidence to be logical and to expect that employees' trust in organization can 
NCC JULRNAL - 2019

have an effect on their emotional commitment (Geyskens- Steenkamp, 1995).

\section{Review of Literatures}

Trust in managers is crucial to mobilize employees and increase their commitment towards realizing a leader vision. Confidence depends on the perceived experience of the leader. At the same time, it also depends on the consistent leader in terms of statements and actions. Robbins and Judge (2007) indicated that there are three types of trust that exist in the organizational relationships. The first one is deterrencebased trust and is usually at the beginning of any organizational relationship. Deterrence-based trust focuses on fear of reprisal if trust is not in place. Deterrence-based trust works when leadership implements punishment with specific consequences. The second one of trust is knowledge based and it relies on the predictability of interactions that occur over time. The parties recognize how to respond the situations and trust grow from this recognition and relationship. Identification-based trust is the third type and routinely arises out of a long relationship such as with married couples who recognize how the other will respond (Robbins and Judge, 2007).

Trust is the word derived from "Trost". In Germany, it connotes comfort. Trust is widely used on a personal level, between groups, organizations, and communities (Cummings and Bromiley, 1996). Trust is the most important part of a bond. According to Blau, (1964), there are two ways to build. They are namely: (1) perform duties on a regular basis, and (2) the development of exchanges in accordance with the passage of time. The trust is usually expressed as one bonding, but in a broader perspective such as social or organizational context, trust has a systemic consequence on structure, process, and operational effectiveness.

Trust is part of the norms and values of the organization and is expressed to have associated with goal setting, risk taking, exchange of information, decision-making, performance management, and collaboration. Trust is the result of a process of very favorable social exchange. High level of trust held subordinate to superiors within organization resulting into higher level of organizational citizenship behaviour from subordinates (Blau, 1964). Various measures are helpful to create trust between the employer and employee, employee trust, supervisor with the organization. According to Blomqvist and Stahle (2000), trust is helpful to build credibility (honesty, competence and inspiring) and trust in the integrity, character, and ability to direct supervisor, whereas confidence in organization is completed by individual beliefs synergized with organization, and through experience of positive behavior of people who believed (Robbins and Coulter, 2005)

Turner (2010) embarks behaviors which represent foundations that direct trusting relationships. The leaders and teams need to recognize behaviors which demonstrate trust within the organization and help train the teams to assess the team members and reinforce the use of the behaviors in all activities. The behaviors that demonstrate trust are: talk straight, be honest, demonstrate respect, create transparency, right wrongs, apologize when necessary, show loyalty, give credit freely, deliver results and complete tasks correctly, confront reality, take issues head one, practice accountability, listen before speaking, understand and diagnose, keep commitments, and extend trust abundantly. Salamon and Robinson (2008) introduced the concept of "felt trustworthiness" and "felt trust," respectively, which they conceptualized as employees' perception of their leaders' trust in them. Being supervised by someone that one does not trust can be psychologically distressing and this distress will likely affect one's job attitudes one such attitude is affective organizational commitment (Dirks and Ferrin, 2002). Kim and Kang (2014) find that entrepreneurship is facilitated by trust (in strangers or public institutions) and is positively associated with parents emphasizing to their children individual achievement relative to interpersonal relationships.

\section{Objectives of this Study}

The main aim of this study is to investigate the component of trust in management among healthcare nursing staff in Nepal. The specific objective of the study is: 
Vol. 4, No. 1

- To determine the factors affecting employees' trust in management at hospital sectors in Nepal.

\section{Research Methodology}

The study was conducted to get an insight into the level of trust in management among healthcare nurses of Nepal. This study represents a research design using the multi-stage purposive sampling so as to understand perceived trust in management practices among nurses at hospitals in Nepal.

\section{Research Design and Instruments}

This study has employed descriptive and analytical research design. This study was carried out at the units of the government and non-government hospital in Nepal, which is affiliated to the Ministry of Health in Nepal. Questionnaire was designed with the modification of the measure used by Mayer and Davis (1999). It incorporates questionnaire of trust in management presented in the form of five point response scale. It consists of twenty one items that covers three components of trust in management including competency, integrity and benevolence. In addition to that, it includes socio demographic data, namely, age, marital status, education level, employment status, length of service and so forth.

\section{Sample}

This study is based on a sample of 465 nurses working in Government and Non- Government Hospitals. The sample was drawn from the population of total nurses registered under Nepal Nursing Council. In determining the sample size, there is no clear explanatory variable that reflect the hospital characteristics and its situation. Hence, the growth rate of hospitals was considered as a basis for determining sample size. The growth rate is used to ensure that even if there is increment in the hospital establishment, it does not effect in the sample size determined. Multi-stage cluster sampling was used for the selection of nurses as respondents from 50 hospitals including 30 government and 20 non-government hospitals. A purposive multi stage sampling technique was used to select the study sample of 465 nurses. The patients had been selected according to the following criteria: age ranged 18-62 years old (b) working in the selected setting for at least 6 months prior to the data collection to be oriented for working conditions, (c) able to express opinion about organizational justice and quality performance, and agree to participate in the study.

\section{Data Analysis}

Data were analyzed using the by using SPSS 16.0 statistical software packages. The analyses included demographics and factor analysis. Factor analysis was conducted to decrease the items into significant factors and their reliability was calculated. The Kaiser-Meyer-Ohlin (KMO) measure of sample adequacy and Bartlett's Test of Sphericity were applied to measure inter-correlation of data. Rotated component matrix of trust in management was used to determine the number of components in which only the eigen values greater than or equal to 1 are considered (Kaiser, 1960).

\section{Demographic characteristics of the sample}

\section{Results}

Here, personal and positional factors such as age, marital status nature of hospitals, the position of the job, work experience of the respondents that influence employees' trust were presented as follows.

Table 1 Demographic characteristics of the sample

\begin{tabular}{|l|l|c|c|}
\hline Attribute & Characteristics & N & $\%$ \\
\hline \multirow{4}{*}{ Age } & Below 30 & 362 & 77.8 \\
\cline { 2 - 4 } & $30-39$ & 46 & 9.9 \\
\cline { 2 - 4 } & 40 and above & 57 & 12.3 \\
\hline
\end{tabular}


NCC JOURNAL - 2019

\begin{tabular}{|l|l|c|c|}
\hline \hline Attribute & Characteristics & $\mathrm{N}$ & $\%$ \\
\hline \multirow{3}{*}{ Marital Status } & Not married & 247 & 53.1 \\
\cline { 2 - 4 } & Married & 218 & 46.9 \\
\hline Duration of service (in years) & 3 & 217 & 46.7 \\
\cline { 2 - 4 } & $3-6$ & 171 & 36.8 \\
\cline { 2 - 4 } & $7-10$ & 62 & 13.3 \\
\cline { 2 - 4 } & More than 10 years & 15 & 3.2 \\
\hline \multirow{5}{*}{ Nature of hospital } & Government & 150 & 67.74 \\
\cline { 2 - 4 } & Non- government & 315 & 45.58 \\
\hline \multirow{2}{*}{ Job level } & Managerial & 212 & 54.42 \\
\cline { 2 - 4 } & Non- managerial & 253 & \\
\hline
\end{tabular}

In this study, the age range below 30 was $77.83 \%(n=362)$, the age between 30 to 39 age was $9.9 \%$ $(\mathrm{n}=46)$, and 40 and above years was $12.3 \%(\mathrm{n}=57)$. It is interesting to note that a large portion of the nurses is younger and less number in 30 to 39 years than 40 and above years. As for organizational tenure, $46.7 \%$ $(n=217)$ of employees had less than 3 years working experience, $36.8 \%(n=171)$ of employees had less than 6 years working experience, $13.3 \%(\mathrm{n}=62)$ of employees had less than 10 years working experience, and $3.2 \%(n=15)$ of employees had more than 10 years working experience in their current profession. Table shows that nearly half of the nursing employees have been occupying a position for less than three years. This could be the result of a large number of new appointments made during the past three years. Two nature of hospitals are categorized involving $32.26 \%(\mathrm{n}=150)$ from government run hospitals and, $67.74 \%(n=315)$ from non-government hospitals. In terms of job level, data show that 54.42 percent $(n=253$ respondents) were in non-managerial level, and 45.58 percent ( $n=212$ respondents) were in managerial level.

\section{Factor Analysis}

Factor analysis was conducted to decrease the items into significant factors and their reliability was calculated. The Kaiser-Meyer-Ohlin (KMO) measure of sample adequacy and Bartlett's Test of Sphericity were applied to measure inter-correlation of data, and thereby the appropriateness of factor analysis. KMO statistics are based on partial correlation and the anti-image correlation of items. Linked to the anti-image correlation matrix is the measure of sampling adequacy (MSA). The scores of MSA can range from zero to one, but the overall score must be higher than 0.7 if the data are likely to factor well (Morgan \& Griego, 1998).

Table $2 \mathrm{KMO}$ and Bartlett's Test of Trust in Management

\begin{tabular}{|l|c|c|}
\hline Kaiser-Meyer-Olkin Measure of Sampling Adequacy & .840 \\
\hline \multirow{4}{*}{ Bartlett's Test of Sphericity } & Approx. Chi-Square & 10039.290 \\
\cline { 2 - 3 } & Df & 210 \\
\cline { 2 - 3 } & Sig. & .000 \\
\hline
\end{tabular}

As indicated in table 2, KMO that measures the sampling adequacy had the value of and it fulfills the criteria mentioned above. The KMO measure of sample adequacy yielded a value of 0.840 , which is above the acceptable value. Besides that, Bartlett's sphericity should produce a significant chi-square value and here it was significant (chi-square is $10039.290, \mathrm{p}<0.001$ ). 
Table 3 Rotated component matrix of trust in management

\begin{tabular}{|c|c|c|c|c|}
\hline Factors & Variables & $\begin{array}{l}\text { Factor } \\
\text { Loading }\end{array}$ & $\begin{array}{l}\text { Reliability } \\
\text { coefficient }\end{array}$ & $\begin{array}{l}\text { Variance } \\
\text { explained }\end{array}$ \\
\hline \multirow{7}{*}{ Competency } & Management is capable of performing its job. & 0.700 & \multirow{7}{*}{0.928} & \multirow{7}{*}{38.651} \\
\hline & $\begin{array}{l}\text { Managers are successful in the work they attempt to } \\
\text { accomplish. }\end{array}$ & 0.833 & & \\
\hline & $\begin{array}{l}\text { Managers have much knowledge about the work that needs } \\
\text { to be done. }\end{array}$ & 0.856 & & \\
\hline & I feel confident about management's skills. & 0.810 & & \\
\hline & $\begin{array}{l}\text { Management has specialized capabilities that can increase } \\
\text { our performance. }\end{array}$ & 0.772 & & \\
\hline & Top management is well qualified. & 0.870 & & \\
\hline & $\begin{array}{l}\text { I am comfortable giving management a problem which is } \\
\text { critical to me, even if I do not monitor their actions. }\end{array}$ & 0.615 & & \\
\hline \multirow{6}{*}{ Integrity } & $\begin{array}{l}\text { Sound principles seem to guide top management's } \\
\text { behavior. }\end{array}$ & 0.792 & \multirow{6}{*}{0.895} & \multirow{6}{*}{22.140} \\
\hline & Managers take actions that are consistent with their words & 0.800 & & \\
\hline & My managers are open and upfront with me. & 0.722 & & \\
\hline & Managers keep the promises they make. & 0.723 & & \\
\hline & $\begin{array}{l}\text { Managers express their true feelings about important } \\
\text { issues. }\end{array}$ & 0.580 & & \\
\hline & I like top management's values & 0.860 & & \\
\hline \multirow{8}{*}{ Benevolence } & My needs and desires are very important to management. & 0.813 & \multirow{8}{*}{0.888} & \multirow{8}{*}{10.025} \\
\hline & Managers are very concerned about my welfare & 0.715 & & \\
\hline & Management would not knowingly do anything to hurt me. & 0.780 & & \\
\hline & Managers look out for what is important to the employees. & 0.554 & & \\
\hline & $\begin{array}{l}\text { I can count on my managers to help me if I have } \\
\text { difficulties with my job. }\end{array}$ & 0.792 & & \\
\hline & $\begin{array}{l}\text { There is a cordial relationship between the managers and } \\
\text { workers in Hospital. }\end{array}$ & 0.838 & & \\
\hline & Managers make personal sacrifices for employees. & 0.543 & & \\
\hline & I admire my supervisor's professional skills. & 0.623 & & \\
\hline
\end{tabular}

Note: Extraction Method: Principal Component Analysis. Rotation Method: Varimax with Kaiser Normalization.

\section{Rotation converged in 5 iterations.}

Table 3 displays the standardized factor loadings of the observed latent variables of organizational justice. It helped to examine the validity of the measures. On examination of the rotated component matrix, the standardized factor loadings were presented to determine the number of components in which only the eigen values greater than or equal to 1 are considered (Kaiser, 1960). While deciding on the number of factors to extract, latent root criteria were used according to the principal component analysis. Using this criterion, only factors having latent roots or eigen values greater than 1 are considered significant. Besides that, the theory pertaining to the certain variable will also be considered in determining the number of factors to be extracted. With regard to the factor loading, according to the Hair et al. (1998), the rule of thumb is that loading of +0.5 and above is preferable. In this context, every factor loading was statistically significant $(\mathrm{p}<0.001)$ and greater than the recommended value of 0.5. (Fornell and Larcker, 1981) and accordingly, three factors were extracted. Twenty-one items of the questionnaire were included in a factor analysis. At the end of the factor analysis, three components are exported with an eigen value above the one. They are labeled as competency, Integrity, and benevolence.

The first component was labeled as "competency". It was operationalized as a part of belief held 
by employees regarding capability, skill, and knowledge by the managers. This component consisted seven items beginning from 9 to 15 . The variance explained by this component was 38.651 percent. The second component was labeled as "integrity". It was a part of management values and its commitment. This component consisted six items beginning from 16 to 21 . The variance explained by this component was 22.140 percent. The third component was labeled as "benevolence". It was a part of the management's reaction and relationship to the welfare of the employees. This component consisted five items beginning from 1 to 8 . The variance explained by this component was 10.025 percent.

\section{Discussion and Conclusion}

This research paper advances a theoretical model stating the factors affecting the employees' trust in management resulted into three variables, which in their order of importance are (a) competency (b) Integrity and (c) benevolence. The findings from this study depict that a number of factors, including competency, integrity and benevolence influence nurses' behavior through organizational trust in management. Relationships are the major issues for the successful operation of management. Management is built around the relationships between employers and employees. At the foundation of all relationships, there require trust. Without each party trusting one another, agreement or consensus on an issue is always going to be compromised. Therefore, managers must pay due attention to the means or the process of decision making for the distribution as it will lead to support in trust in management.

These findings provide implications for hospital management to encourage an environment that should promote efficiency, outcomes and productivity in the organization. Successful hospital managers create an environment that aligns the goals, practice and behaviour of nursing employees with the goals of the organization and public policy (Casida\& Pinto-Zipp, 2008). A culture of trust has direct impact on the organizational commitment within organization. Managers have an important responsibility in building and sustaining the culture of trust among employees. To build and sustain a culture of trust, managers must understand the values of people working in the organization. He is to perform what is in the best interest of others within the organization. Employees should lead through values and the principles. Managers must incorporate the input of all employees in solving problems and making-decisions. At the same time, he must constantly get feedback about his action and concern for how best he can serve and invest in employees.

\section{References}

Adams, J. (1965). Inequity in Social Exchange. In L. Berkowitz (ed): Advances in Experimental Social Psychology. New York: Academic Press, 267-299.

Adhikari, D. R. (2009). Human Resource Management, Kathmandu: Buddha Academic Enterprises Pvt. Ltd.

Adhikari, D. R. and Gautam, D. K. (2010), Labour legislations for improving quality of work life in Nepal, International Journal of Law and Management, 52, 1, 40-53.

Alexander, S., and Ruderman, M. (1987). The role of procedural and distributive justice in organizational behavior. Social Justice Research, 1, 177-198.

Allen, N.J and J.P Meyer (1990). The measurement and antecedent of affective, continuance, and normative commitment to the organization, Journal of Occupational Psychology, Vol. 63

Aryee, S., Budhwar, P. S., \& Chen, Z. X. (2002). Trust as a mediator of the relationship between organizational justice and work outcomes: Test of a social exchange model. Journal of Organizational Behavior, 23, 267-285.

Bakshi ,A., Kumar, K., \& Rani , E. (2009). Organizational justice perceptions as predictor of job satisfaction and organization commitment. International Journal Business Management, 4(9): 145-154.

Baron, R. M and D.A Kenny (1986). The mediator-mediator variable distinction in social psychological research: conceptual, strategic, and statistical considerations, Journal of Personality and Social 
Vol. 4, No. 1

Psychology,51, 1173-1182.

Bies, R.J and Moag, J.S. (1986). International Justice: communication criteria of fairness. Research on Negotiation in Organizations. (Vol. 1). Greenwich, CT: JAI Press, 43-55.

Blau, Peter M. (1964). Exchange and Power in Social Life. New York: Wiley

Blomqvist, K., \&Stahle, P. (2000). Building organizational trust. Paper presented at the 16th Annual IMP Conference, Bath, UK

Brown, W.A and Yoshioka, C.F. (2003), Mission Attachment and Satisfaction in Employee Retention, Nonprofit Management and Leadership, 14 (1): 5-18.

Cummings, L.L., \&Bromiley, P. (1996), The organizational trust inventory (OTI): development and validation, in Kramer, R.M. and Tyler, T.R. (Eds), Trust in Organizations, Sage, Thousand Oaks, CA, 302-330.

Dirks, K. T., \&Ferrin, D. L. (2000). The effects of trust in leadership on employee performance, behaviors, and attitudes: A meta-analysis. Academy of Management Meeting Best Papers Proceedings

Cohen-Charash, Y., \& Spector, P.E. (2001). The role of justice in organizations: A meta-analysis.

Organizational Behavior and Human Decision Processes, 86, 278-324.

Colquitt, J.A.(2001). On the dimensionality of organizational justice: A construct validation of a measure. Journal of Applied Psychology, 86, 386-400.

Cook, J., \& Crossman, A. (2004). Satisfaction with performance appraisal system, Journal of Managerial Psychology, 19 (5): 526-541.

Cropanzano, R. and Greenberg, J. (1997). Progress in Organizational Justice: Tunneling Through the Maze, International Review of Industrial and Organizational Psychology, 12, 317-372.

Folger, R., \&Konovsky, M.A. (1989). Effects of procedural and distributive justice on reactions to pay raise decision. Academy of Management Journal, 32, 115-130.

Foster, D. P, B. Stine and R. Waterman (1998). Business Analysis Using Regression: A Casebook. Berlin: Springer-Verlag.

Ghimire, B. (2012). Organizational Justice and its impact with reference to Nepal. Germany: Lap Publishing Greenberg, J. (1990). Organizational Justice: Yesterday, Today and tomorrow, Journal of Management, 16, 399-432.

Hair, J. F, R.E Anderson, R.L Tatham and W.C Black (1998). Multivariate Data Analysis. Englewood Cliffs, NJ: Prentice Hall.

Hartman SJ, Yrle AC, Galle Jr. WP (1999). Procedural and distributive justice: examining equity in a university setting, Journal of Business Ethics., 20(4): 337-351.

Huff, L., \& Kelley, L. (2003). Levels of organizational trust in individualist versus collectivist societies: A seven-nation study. Organization Science, 14, 81-90.

James, K. (1993). The social context of organizational justice: Cultural, intergroupand structural effects on justice behaviors and perceptions. In R. (. Cropanzano, justice in the workplace: Approaching fairness in human resource management 21-50. Erlbaum: Hillside, NT.

Kim and Kang (2014), Social capital and entrepreneurial activity: a pseudo-panel approach, J. Econ. Behav. Org., 97: 47-60

Konovsky, M., and Paugh, D. (1994), Citizenship behavior and social exchange, Academy of Management Journal, 37 (3): 656-669.

Konovsky, M. (2000). Understanding procedural justice and its impact on business organizations, Journal of Management, 26, pp. 489-511

Krugman, M., Smith, K., Goode, C.J.,(2000) A clinical advancement programme: evaluating 10 years of $\sim 37 \sim$ 
progressive change. Journal of Nursing Administration 30(5), 215-225.

Lee, C., Law, K., \&Bobko, P. (1999). The importance of justice perceptions on pay effectiveness: a two year study of a skill-based pay plan. Journal of Management, 25, 851-874.

Lind, E. A., \& Tyler, T. R. (1988). The social psychology of procedural justice. New York: Plenum Press.

Luthans, Freed., (1996). Organizational Behavior. New York: McGraw Hill Book Companion.

Meyer, J.P, N.J Allen, I.R Gellatly, R.D Goffin and D.N Jackson (1989). Organizational commitment and job performance: It's the nature of the commitment that counts, Journal of Applied Psychology, 74: 152.

Masterson, S.S., Lewis, K., Goldman, B.M. and Taylor, M.S. (2000), "Integrating justice and social exchange: the differing effects of fair procedures and treatment on work relationships", Academy of Management Journal, 43: 738-48.

McFarlin, D. B., \& Sweeney, P. D. (1992). Distributive and procedural justice as predictors of satisfaction with personal and organizational outcomes. Academy of Management Journal, 35(3), 626-637.

Mikula, G., Petrik, B., Tanzer, N. (1990). What people regard as unjust: types and structures of everyday experiences of injustice. European Journal of Social Psychology. 20(2): 49-133.

Moorman, R. H. (1991). Relationship between organizational justice and organizational citizenship behaviors: Do fairness perceptions influence employee citizenship? Journal of Applied Psychology, 76(6),845-855.

Mowday, R. T, R.M Steers and L.W Porter (1979). The measurement of organisational commitment, Journal Vocational Behavior, 14: 224-247.

Nunally, J. C and I.H Bernstein (1994). Psychometric Theory. New York: McGraw-Hill.

Niehoff, B.P., \& Moorman, R.H. (1993). Justice as mediator of the relationship between methods of monitoring and organizational citizenship behavior, Academy of Management Journal, 369(3): 527556.

Pandey, D. L. ( 2008), Expected training benefit and organizational commitment: A study of Nepalese Service Sector, unpublished M. Phil. Thesis submitted to Faculty of Management, Tribhuvan University, Nepal.

Ponnu CH, Tennakoon G (2009). The association between ethical leadership and employee outcomes: The Malaysian case', Electronic. Journal of Business Ethics.., 14(1): 21-31.

Rhodes, Susan R. and Steers, R. M. (1981). Conventional vs. Worker Owned Organizations. Human Relations 43 (12): 1013-1035.

Robbins, S.P., \& Judge, T.A. (2007). Organizational Behavior (12th. ed.). Prentice Hall

Robbins, Stephen P dan Coulter, Mary, (2005). Manajemen, Edisiketujuh, Jilid 2,TerjemahanSarwijidan Hermaya, Penerbit PT IndeksKelompokGramedia, Jakarta.

Robinson, L. L., \& Morrison, E. W. (1995). Organizational citizenship behavior: A psychological contract perspective, Journal of Organizational Behavior, 15: 289-298

Sekaran, Uma. (2000). Research Methods for Business: A Skill Building Approach. John Willey \& Sons, Inc

Sheppard B, Lewicki R and Minton J (1992), Organizational Justice: The Search for Fairness in the Workplace, Lexington.

Shrestha, Y. K. (2006), Human resource management and organizational performance: an evidence from

Nepalese Banking Industry, unpublished thesis, M.Phil. in Management, Tribhuvan University, Kathmandu.

Vecchio, P. R, G. Hearn and G Southey (1992). Organizational Behavior. Sydney: Harcourt.

Warr, P. B, J Cook and T.D Wall (1979). Scales for the measurement of some work attitudes and Aspects of 
Vol. 4, No. 1

psychological well-being, Journal of Occupational Psychology, 52: 129-148.

Whitener E. M. (1997). The impact of human resource activities on employee trust. Human Resource Managem ent Review 7:389-404.

Wong, C. S., and Kung, H. L. (1999). An exploratory investigation on commitment to specific constituencies in Taiwan. Chinese Journal of Psychology, 40(1), 1-13.

Rousseau, D., Sitkin, S., Burt, R., \&Camerer, C. (1998). Not so different after all: A cross-discipline view of trust. Academy of Management Review, 23, 393-404.

Spector, P.E.(1997) Job satisfaction; Application, Assessment, Causes and Consequences. SAGE Publication, London.

Sun Y.F., Yan, L.H,Kong.,(2001) The psychological reasons and counter measures for nurses leaving their positions. Chinese Journal of Nursing 36(2), 92-94.

Sweeney, P. D., and McFarlin, D. B. (1993). Workers' evaluations of the "ends" and the "means": An examination of four models of distributive and procedural justice. Organizational Behavior and Human Decision Processes, 55, 23-40. 